\title{
Pragmatic approaches for effective management of pelagic marine protected areas
}

\author{
Sara M. Maxwell ${ }^{1,2, *}$, Natalie C. Ban ${ }^{3}$, Lance E. Morgan ${ }^{1}$ \\ ${ }^{1}$ Marine Conservation Institute, 14301 Arnold Dr., Suite 25, Glen Ellen, CA 95442, USA \\ ${ }^{2}$ Stanford University, Hopkins Marine Station, 120 Oceanview Blvd, Pacific Grove, CA 93950, USA \\ ${ }^{3}$ University of Victoria, School of Environmental Studies, PO Box 3060 STN CSC, Victoria, BC V8W 3R4, Canada
}

\begin{abstract}
The dynamic nature of pelagic environments presents unique challenges for management. Despite the sharp increase in the number of marine protected areas (MPAs) with large pelagic areas, or pelagic marine protected areas (PMPAs), little literature exists regarding on-theground approaches to their management, in large part due to the relative newness of many largescale PMPAs. Here we attempt to highlight pragmatic solutions or recommendations for the management challenges of PMPAs, particularly regarding setting objectives, monitoring and compliance, drawing from examples of existing PMPA management when possible. We suggest using techniques such as structured decision making and multi-criteria decision analysis for setting management objectives and actions and reducing conflict that will be inherent across the multi-agency, multi-objective landscape of PMPAs. We suggest cost-effective strategies for monitoring of complex pelagic interactions and far-ranging species, including tiers of monitoring importance linked to funding levels, and highlight means of determining when monitoring is a necessity. Finally, we highlight techniques to increase compliance within PMPAs, such as participatory monitoring. We focus on enforcement across the large scales of PMPAs, such as setting and effectively integrating biological and enforcement priorities, and implementing cost-effective enforcement, particularly in remote regions, using techniques such as international enforcement partnerships and enforcement technologies. Our goal is not to give a complete framework for PMPA management, but to collate existing lessons and provide a baseline for managers to build from, and to provide insight for scientists looking to focus research efforts to aid in management of protected pelagic ecosystems.
\end{abstract}

KEY WORDS: Enforcement - Monitoring - Priority setting - Systematic conservation planning · Participatory enforcement $\cdot$ Dynamic management $\cdot$ Migratory marine species

\section{INTRODUCTION}

Pelagic ecosystems encompass the greatest volume of the world's oceans (Angel 1993), yet face a number of threats including overfishing, pollution, climate change, ocean acidification, shipping, eutrophication, and species introductions (Halpern et al. 2008, Game et al. 2009, Maxwell et al. 2013). Protecting pelagic ecosystems will be critical to meeting global marine conservation targets, such as the Convention on Biological Diversity's (CBD) call to protect $10 \%$ of

\footnotetext{
${ }^{*}$ Corresponding author: maxwells@stanford.edu
}

the worlds' oceans through marine protected areas (MPAs) by 2020 (Convention on Biological Diversity 2010). To meet these targets, there has been an increasing trend in recent years to create large-scale, mostly pelagic marine protected areas (PMPAs) (Table 1, Fig. 1) (McCrea-Strub et al. 2011). These PMPAs may be large enough to guard against threats and incorporate key portions of far-ranging or migratory animal habitats and movements (Hyrenbach et al. 2000, Norse 2005, Alpine \& Hobday 2007, Ardron et al. 2008, Game et al. 2009).

() The authors 2014. Open Access under Creative Commons by Attribution Licence. Use, distribution and reproduction are unrestricted. Authors and original publication must be credited. 
Table 1. Marine protected areas larger than $75000 \mathrm{~km}^{2}$ with large pelagic ecosystem components that were created for purposes beyond single-species objectives. MNM: marine national momument; MPA: marine protected area; OSPAR: Oslo Paris Commission; CCAMLR: Commission for the Conservation of Antarctic Marine Living Resources; NEAFC: North East Atlantic Fisheries Commission; USFWS: United States Fisheries and Wildlife Service; nmi: nautical miles

\begin{tabular}{|c|c|c|c|c|}
\hline Name & Size & Year & $\begin{array}{l}\text { Administrative } \\
\text { body }\end{array}$ & Management measures \\
\hline $\begin{array}{l}\text { Australian } \\
\text { Commonwealth } \\
\text { Marine Reserve } \\
\text { Network }\end{array}$ & $3100000 \mathrm{~km}^{2}$ & 2012 & Australia & $\begin{array}{l}\text { Management plans in development for some areas, but planned multiple use in } \\
\text { areas except marine national parks which are zoned as no-take. Macquarie } \\
\text { Island Commonwealth Reserve (established 1999; } 162000 \mathrm{~km}^{2} \text { ) prohibits mining } \\
\text { and recreational fishing; commercial fishing and scientific research (other than } \\
\text { demersal trawl) requires permits. The largest no-take area is the Coral Sea } \\
\text { Commonwealth Reserve which is } 989842 \mathrm{~km}^{2}\end{array}$ \\
\hline $\begin{array}{l}\text { Cook Islands } \\
\text { Marine Park }\end{array}$ & $1065000 \mathrm{~km}^{2}$ & 2012 & Cook Islands & Management plan in development for multiple use \\
\hline $\begin{array}{l}\text { South Georgia \& } \\
\text { South Sandwich } \\
\text { Islands MPA } \\
\text { Protected Area }\end{array}$ & $1000700 \mathrm{~km}^{2}$ & 2012 & United Kingdom & $\begin{array}{l}\text { Includes } 20431 \mathrm{~km}^{2} \text { of no-take area. Bottom trawling is prohibited throughout, } \\
\text { bottom fishing in areas shallower than } 700 \mathrm{~m}\end{array}$ \\
\hline $\begin{array}{l}\text { Chagos Protected } \\
\text { Area }\end{array}$ & $640000 \mathrm{~km}^{2}$ & 2010 & United Kingdom & No commercial fishing allowed \\
\hline $\begin{array}{l}\text { Phoenix Islands } \\
\text { Protected Area }\end{array}$ & $408250 \mathrm{~km}^{2}$ & 2006 & Kiribati & $\begin{array}{l}\text { Permits are required for science, cultural, management, or educational studies; } \\
\text { specimen collection; tourism operators; tourist visits. All Kiribati fishing vessels } \\
\text { larger than } 7 \mathrm{~m} \text { have to be licensed. All fishing restricted within } 12 \mathrm{nmi} \text { of the } \\
\text { Phoenix Islands. Purse seining restricted within } 60 \mathrm{nmi} \text { of Kanton Island }\end{array}$ \\
\hline $\begin{array}{l}\text { Papahānaumokuākea } \\
\text { MNM }\end{array}$ & $362074 \mathrm{~km}^{2}$ & 2006 & USA & $\begin{array}{l}\text { Entering the monument requires permit. Exemptions for uninterrupted passage, } \\
\text { law enforcement, armed forces activities, emergencies response. No commercial } \\
\text { fishing is allowed. Fishing is allowed under Native Hawaiian Use permit for sus- } \\
\text { tenance at Midway Atoll }\end{array}$ \\
\hline $\begin{array}{l}\text { Great Barrier Reef } \\
\text { Marine Park } \\
\text { (GBRMP) }\end{array}$ & $345400 \mathrm{~km}^{2}$ & 1975 & Australia & $\begin{array}{l}\text { Zoning plans define what activities can occur in which locations. More than } 33 \% \\
\text { of the GBRMP is no-take }\end{array}$ \\
\hline $\begin{array}{l}\text { Northeast Atlantic } \\
\text { high seas areas }\end{array}$ & $287311 \mathrm{~km}^{2}$ & 2010 & OSPAR & $\begin{array}{l}\text { No regulations as of yet; however, most overlap with NEAFC bottom fishing } \\
\text { closures }\end{array}$ \\
\hline $\begin{array}{l}\text { Marianas Trench } \\
\text { MNM }\end{array}$ & $246608 \mathrm{~km}^{2}$ & 2009 & USA & $\begin{array}{l}\text { Management plan in development. No commercial fishing allowed in Islands Unit } \\
\text { of MNM }\end{array}$ \\
\hline $\begin{array}{l}\text { Pacific Remote } \\
\text { Islands MNM }\end{array}$ & $225040 \mathrm{~km}^{2}$ & 2009 & USA & $\begin{array}{l}\text { No commercial fishing allowed. USFWS permits non-commercial sport fisheries at } \\
\text { Palmyra Atoll. NOAA manages fishing activities in the US Exclusive Economic } \\
\text { Zone }\end{array}$ \\
\hline $\begin{array}{l}\text { Prince Edward } \\
\text { Islands Marine } \\
\text { MPA }\end{array}$ & $180000 \mathrm{~km}^{2}$ & 2009 & South Africa & $\begin{array}{l}\text { Fishing ban within } 22.2 \mathrm{~km} \text { of the Islands. Limited fishing and other activities sea- } \\
\text { ward of this } 22.2 \mathrm{~km} \text { zone. Some limited fishing to monitor fish populations may } \\
\text { be allowed within a few restricted areas }\end{array}$ \\
\hline $\begin{array}{l}\text { Motu Motiro Hiva } \\
\text { Marine Park }\end{array}$ & $150000 \mathrm{~km}^{2}$ & 2010 & Chile & Designated as a no-take area \\
\hline $\begin{array}{l}\text { Galapagos Marine } \\
\text { Reserve }\end{array}$ & $133000 \mathrm{~km}^{2}$ & 1998 & Ecuador & $\begin{array}{l}\text { The reserve is split into } 3 \text { main zones: a multi-use zone, a limited-use zone, and a } \\
\text { port zone. These } 3 \text { main zones are split further into a number of subzones. Within } \\
\text { the limited-use zones are some areas designated as non-extractive areas }\end{array}$ \\
\hline $\begin{array}{l}\text { Marine Park of } \\
\text { the Glorieuses \& } \\
\text { Marine Park of } \\
\text { Mayotte }\end{array}$ & $110000 \mathrm{~km}^{2}$ & 2012 & France & Management plan in development \\
\hline $\begin{array}{l}\text { South Orkney } \\
\text { Islands Southern } \\
\text { Shelf MPA }\end{array}$ & $93818 \mathrm{~km}^{2}$ & 2010 & CCAMLR & Designated as a no-take area \\
\hline $\begin{array}{l}\text { Pelagos Marine } \\
\text { Sanctuary }\end{array}$ & $87492 \mathrm{~km}^{2}$ & 2005 & $\begin{array}{l}\text { France, Italy, } \\
\text { Monaco via the } \\
\text { Extraordinary } \\
\text { Conference of } \\
\text { the Parties of } \\
\text { the Sanctuary }\end{array}$ & $\begin{array}{l}\text { Management plan has been created though not implemented yet; currently, there } \\
\text { is no timeline for implementation. The management plan calls for the prohibition } \\
\text { of gillnet fishing, addressing threats to cetaceans with clear, targeted manage- } \\
\text { ment actions and monitoring impacts of whale watching and high-speed boating }\end{array}$ \\
\hline
\end{tabular}

Many PMPAs, however, have only recently been designated or are in development stages, and very few have been in existence long enough to draw lessons relevant for the management of PMPAs elsewhere. Thus, appropriate management goals for these large protected areas and scientific evidence for their success have yet to be established (Gaines et al. 2010). The Big Ocean Network (www.bigoceanmanagers. org/) provides a forum for managers of large, mostly pelagic MPAs to communicate about challenges and 


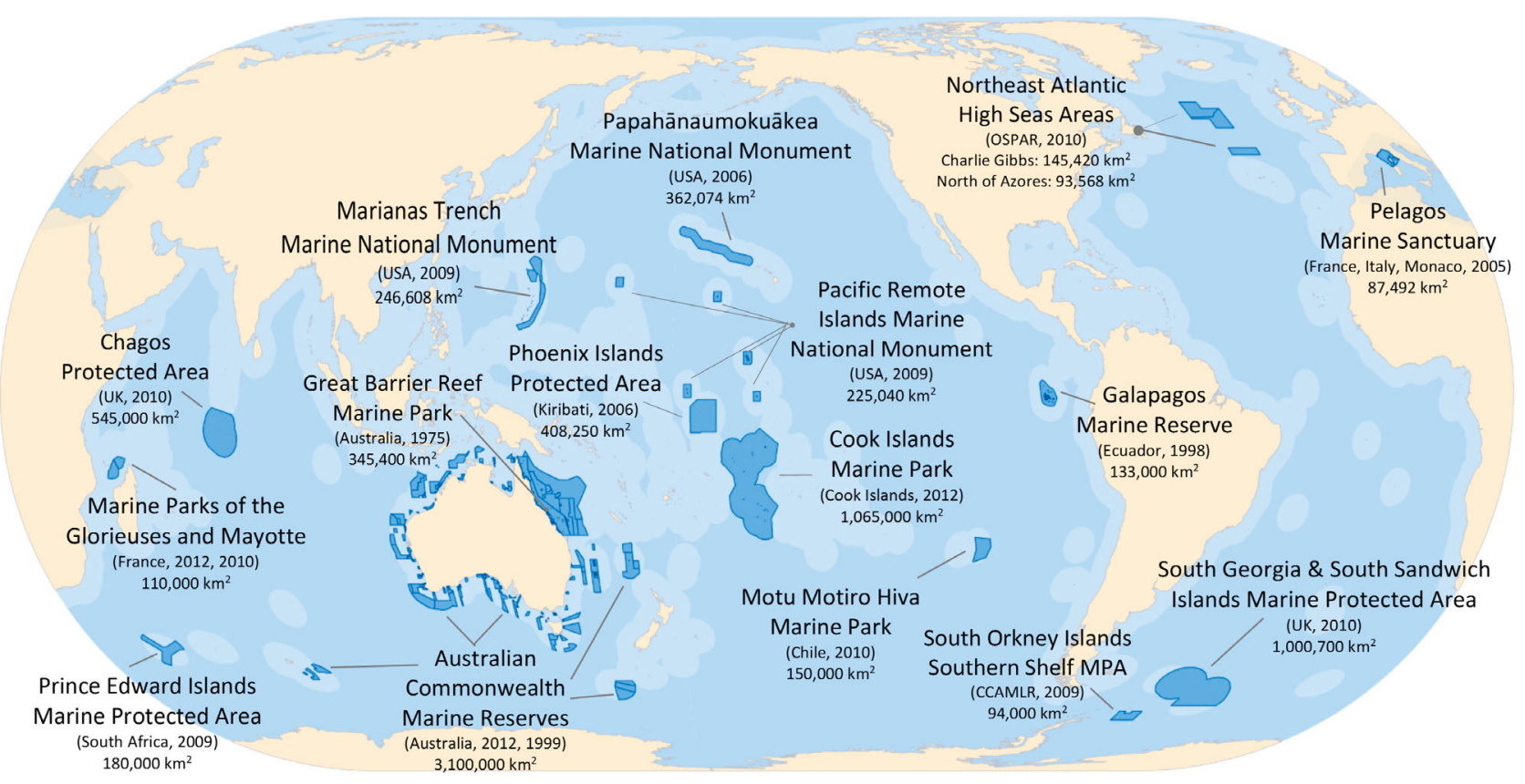

Fig. 1. Marine protected areas (MPAs) with large pelagic components. Image credit: Beth Pike, Marine Conservation Institute. Administrative bodies and years in which the MPAs were founded are also given

successes in management (Toonen et al. 2013). However, many insights from this group have not been formally captured. Thus, while key ecological, social, and political ideas for marine conservation planning in pelagic ecosystems have been considered elsewhere (Ban et al. 2014a,b), a cohesive review of existing lessons and their implications for PMPA management has not been conducted. Below we outline management considerations specific to PMPAs, based on discussions with PMPA managers and arising from a Marine Think Tank entitled 'Pelagic ecosystems and management of marine protected areas', held during the International Congress for Conservation Biology in Auckland, New Zealand, in December 2011. We attempt to offer pragmatic solutions or recommendations for key management challenges of PMPAs, drawing from examples of existing PMPA management when possible. This information was compiled through a review of scientific and grey literature, as well as management plans. Interviews with managers of existing PMPAs and individuals with key roles in the implementation or management process, and discussions at the Marine Think Tank, all informed our approach and the information presented.

In this paper we first focus on setting management goals and objectives, and identifying priorities for management action. Next we discuss monitoring key components of PMPAs to assist management decision-making, and finally we consider compliance and enforcement of PMPAs. In particular, all sections focus on cost-effectiveness and frequently use the US Pacific Remote Islands Marine National Monument (PRIMNM) as a management example, because this work was originally motivated by a request from the NOAA to develop a guidance document for PRIMNM management (Maxwell \& Morgan 2012). While we fall short of a comprehensive overview of effective PMPA management, our aim is to provide a framework that managers can build upon, as more areas are designated and more management experience is accumulated.

\section{DETERMINING MANAGEMENT ACTIONS AND PRIORITIES}

For many recently designated PMPAs management objectives and plans are still being defined and created (e.g. Chagos Marine Reserve, PRIMNM). Scientists and managers have already established that effective MPAs, regardless of size or location, must have clearly articulated goals and measurable objectives (Hocking et al. 2000, Pomeroy et al. 2004, Notarbartolo-Di-Sciara et al. 2008, Hooker et al. 2011, Sowman et al. 2011, Thorpe et al. 2011). Commonly, the overarching goals are articulated at designation. Ensuring that goals are clear and that measurable objectives for achieving those goals are 
articulated will be similarly important for PMPAs, particularly given data limitations in these areas even in more developed countries - and the conflicting mandates that may occur. Guidance for setting objectives can be found elsewhere (e.g. Tear et al. 2005); thus, here we focus on providing approaches for prioritizing management and monitoring actions, specifically for PMPAs. The dynamic nature of oceanographic features within PMPAs necessitates additional considerations for managers beyond those of most coastal MPAs. Below we first outline a general approach for determining management actions and priorities, and then highlight a few of the considerations facing PMPAs: (1) cost-effectiveness, (2) conflicting mandates, (3) multi-agency coordination, and (4) threats beyond PMPA boundaries.

\section{Cost-effective approaches}

An approach gaining traction in conservation literature and practice is to prioritize management actions based on their cost-effectiveness for achieving conservation objectives (Carwardine et al. 2012). This approach emerged from the decision sciences and, more specifically, is a form of structured decision-making (SDM). It is simple, user-friendly, and can combine available information and scientific expertise. Several questions are formulated based on data and expert opinions: What are the key management actions for achieving the stated objectives? What components of biodiversity/ecological integrity benefit from the management action (in conservation planning terms, what are the key features)? What is the benefit to these features for each management action compared to a 'do nothing' scenario? What is the feasibility of implementing the management actions? And how much do the management actions cost over a given time horizon (e.g. 20 yr)? A simple spreadsheet can then be used to assess the costeffectiveness, including feasibility, of the management actions under consideration (Carwardine et al. 2012). If data for these questions are not available, experts can provide estimates. Methods for expert elicitation have been refined and provide guidance for obtaining these estimates (Martin et al. 2012).

Perhaps most importantly for PMPAs, cost-effectiveness approaches such as SDM provide a framework for formalizing the intrinsic knowledge of experts in the context of complex scenarios with conflicting objectives, while also providing a means of integrating science and uncertainty into the process. Furthermore, decision-makers and stakeholders are critical to the SDM process. SDM has been applied to determine incidental take allowances under the Endangered Species Act and to aid in ecosystembased management and other fisheries applications (Espinosa-Romero et al. 2011, Irwin et al. 2011, McGowan 2013). Creating explicit, periodic mechanisms for review/revision as new information becomes available and/or the conservation priorities change is also critical.

\section{Deling with conflicting mandates}

Prioritizing conservation actions for implementation can be particularly difficult when there are conflicts among management objectives. This is especially likely in PMPAs given the jurisdiction of multiple agencies. For example, in PRIMNM, management objectives will likely include conservation actions for both seabirds and pelagic fishes. These 2 objectives may conflict, as a management action that increases seabird populations has the potential to reduce pelagic fish populations through ecological interactions (Maxwell \& Morgan 2013). One approach for addressing such conflicting objectives is to use the cost-effectiveness approach outlined above (e.g. through SDM), as it can identify the management action that ensures the most benefit to both suites of species. Another way of managing conflicting objectives is to create a hierarchy of management objectives, detailing how conflicting management objectives should be handled by identifying conflicts a priori. This has been suggested for the Papahānaumokuākea Marine National Monument, where conflicts exist between Galapagos sharks Carcharhinus galapagensis that predate Hawaiian monk seals Monachus schauinslandi (Gerber et al. 2011, Lowry et al. 2011, Marcot et al. 2012).

A specific challenge of resource management, and one inherent to PMPAs, is determining strategies when management objectives cannot be evaluated using common currencies (e.g. tourism revenue versus seabird productivity). Multi-criteria decision analysis (MCDA) has proven a productive strategy to determine effective management objectives when interests are conflicting, when data limitations make decisions difficult, and/or when common currencies do not exist (Brauers et al. 2008, Dichmont et al. 2013). MCDA has been applied effectively in fisheries management (Dichmont et al. 2013), and applications to PMPAs are likely to be similarly effective. For example, MCDA was used to balance sustainability, economic and social objectives, and manage- 
ment strategies across stakeholders and agencies in the Queensland East Coast Trawl Fishery through a quantified process (Dichmont et al. 2013). An expert opinion solicitation was used to determine objectives for management, and stakeholders and expert groups determined potential management strategies to achieve these objectives. Effectiveness of the strategies was quantified and weighted across objectives to determine which strategies were likely to have the optimal outcome. Of particular importance, key data for accessing each of the management objectives varied widely (e.g. stock assessments for key species, economic data); however, through this process, management strategies that would benefit best across all objectives still emerged. Efficiency frontiers represent another avenue for evaluating management strategies across widely varying management objectives (White et al. 2012).

Developing a hierarchy of management objectives using MCDA processes, and assessing the cost-effectiveness of key management actions at achieving the objectives, has the potential to work well with PMPAs. For example, a MCDA and cost-effectiveness process can help determine PRIMNM management objectives and actions, across potentially conflicting mandates such as protection of pelagic fishes and seabirds. This kind of pre-structured decisionmaking can aid in both reducing conflict and the financial costs associated with conflicts and in speeding management action when ecological resources are at risk (Costello et al. 2008, 2010, Gaines et al. 2010). This kind of approach may be particularly applicable for PMPAs because so little is known about pelagic systems and how species and ecosystems interact (Game et al. 2009, Maxwell \& Morgan 2013).

\section{Coordination and conflict among multiple agencies}

An additional challenge that may arise in PMPA management is multi-agency jurisdictions. Because PMPAs are often large and responsible for managing multiple species and habitats, management is likely to fall under different agencies or institutional authorities either by region (e.g. state and federal waters) or by species (e.g. fishery and protected species resource authorities). Designating strategies and frameworks to coordinate multiple agencies is key to effective and efficient management, as well as to reducing conflicts. Techniques such as MCDA and cost-effectiveness analysis are likely to work well in reducing interagency conflict, as was found in the
Queensland East Coast Trawl Fishery where the fishery is managed by fisheries agencies, but also falls within the boundaries of the Great Barrier Reef Marine Park (Dichmont et al. 2013). Similarly, in the management plan for the Phoenix Islands Protected Area (PIPA) in Kiribati, managers have outlined the detailed responsibilities of individual agencies, and also plan to establish a council specifically dedicated to resolving interagency disagreements when they arise. Further, they have a designated plan and specific language to ensure that agencies are provided with adequate structure and financial backing to carry out their responsibilities.

\section{Threats beyond PMPA boundaries}

Because of the size of PMPAs, management objectives should ideally take into account the ability of PMPAs to mitigate threats that exist beyond their borders, in order to be effective for wide-ranging species or large-scale processes (Game et al. 2009, Ban et al. 2010). Identifying these threats can be a starting point for interagency and international cooperation. To do this, the limitations of PMPAs can be explicitly stated in the management objectives. Explicitly quantifying targets may be difficult, but targets could be determined using expert opinion, such as the Delphi technique. For example, in the Great Barrier Reef Marine Park, researchers used the Delphi technique to establish the risks facing dugongs in the park and to quantify the impacts explicitly and spatially. Using this technique, they found that $96 \%$ of dugong habitat is well protected, and they used these findings to prioritize risk management in the remaining areas (Grech \& Marsh 2008). Quantifying targets for more mobile species may be more difficult, but would allow managers to set realistic objectives.

\section{MONITORING IN PMPAS}

Monitoring within PMPAs may be conducted for a number of reasons: (1) to trigger management actions within an adaptive framework; (2) to audit management decisions or environmental programs; (3) to learn about a system; (4) to educate or inform the public and policy makers; and/or (5) to collect longterm background data on a component of the human or ecological system within a PMPA (McDonaldMadden et al. 2010). The motivation most common for managers, however, is to collect data that will in- 
form management, ideally within an iterative, adaptive framework that ties monitoring to management actions (Pomeroy et al. 2004, Pressey \& Bottrill 2009). However, monitoring species, habitats, and MPA effectiveness can be costly, particularly over the spatial scale of PMPAs. Thus, to be the most cost-effective, monitoring resources should be carefully allocated, with particular attention being paid to statistical power in designing monitoring programs (Field et al. 2007). A recent decision framework created to determine if monitoring is necessary to achieve a specific objective may be particularly useful to PMPA managers as it can be used to guide cost-effective monitoring (McDonald-Madden et al. 2010) (Fig. 2). The decision tree developed for this framework highlights a number of places where scientific or management

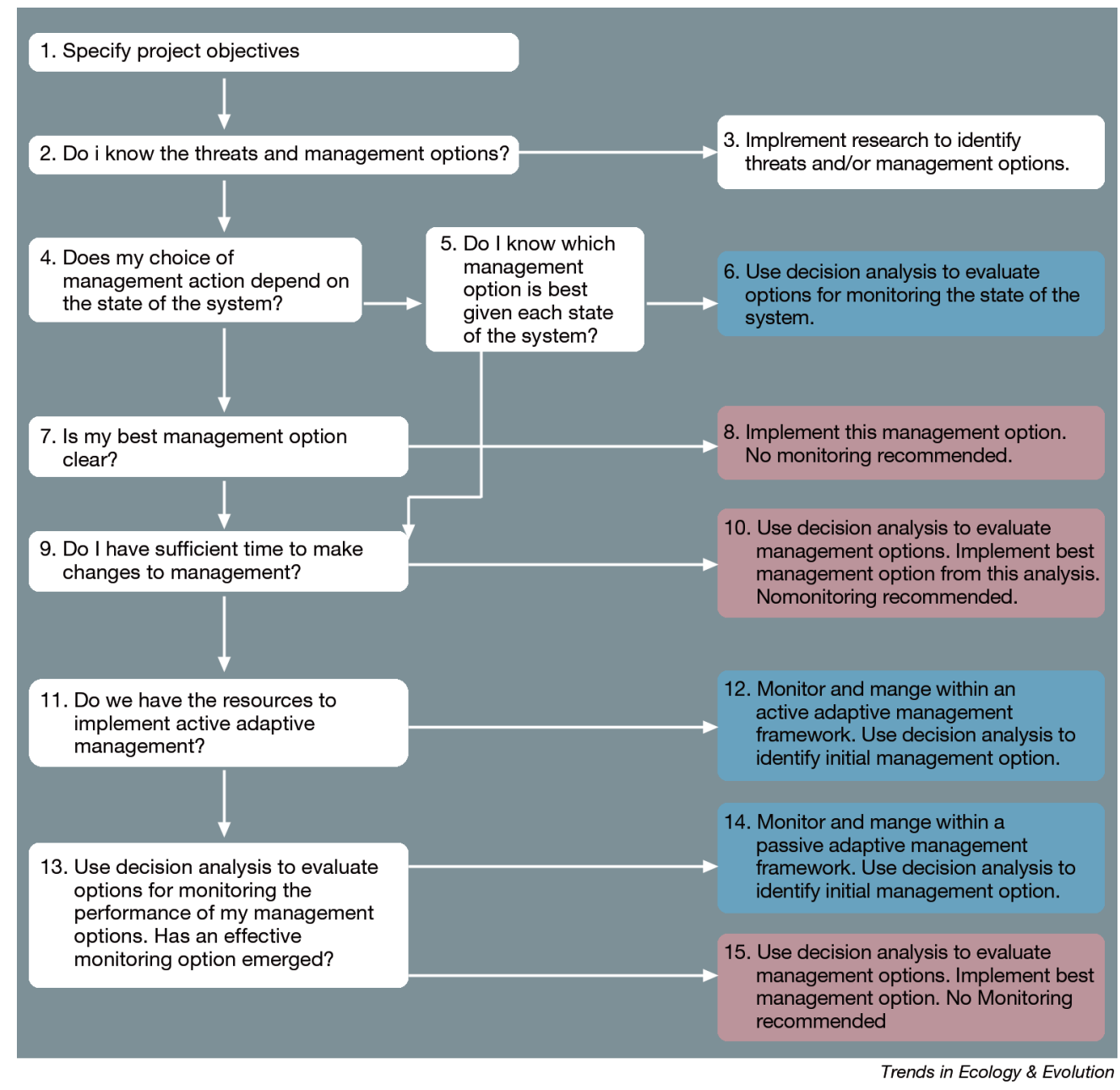

Fig. 2. Making decisions about monitoring. The first step in the monitoring decision tree is to clearly state the objective(s) of the conservation program (Question 1, Q1). Objectives must be realistic, explicit, measurable, and relevant to management. The second step is a review of existing information on threats and the possible management options to address those threats (Q2). Where threats and management actions are well understood (the certainty attached to the term 'well' will be a case-specific quantity), the next step is to assess whether monitoring can usefully inform management (Q4, 5, 7). However, it is also important not to delay management simply because of imperfect knowledge about management actions. See 'Monitoring in 'PMPAS' for examples of these assessments in practice. The fourth step is to consider constraints (most notably time [Q9] and resources [Q11]) on our ability to implement the type of monitoring or research that is needed. Even if considerable financial or human resources are available, there may not be sufficient time to correctly identify trends or incorporate monitoring results into future management. Where insufficient resources exist for active adaptive management, an assessment of other monitoring options might identify alternate cost-effective strategies (Q13). Working through this decision tree yields recommendations on whether and how to implement monitoring for management (Recommendations 3, 6, 8, 10, 12, 14, 15). In some cases, monitoring might not be possible or justified, given, for example, the urgency of the conservation issue or where only 1 clear management option exists. In all cases, monitoring for reasons other than improving management must be considered after progressing through this decision tree (reprinted from McDonald-Madden et al. (2010) by permission of Trends in Ecology and Evolution) 
information may be limited (Qs 2, 4, 5, 7, 9) and gives guidance on whether monitoring can help clarify the means of achieving objectives. It is important to note that in some instances, management decisions will not be effectively informed by monitoring, and thus resources may be better applied elsewhere.

\section{Baseline data on human use and ecological conditions}

Determining management objectives for a PMPA will help guide baseline data collection early in a PMPA's existence. For all MPAs, baseline surveys at the time of designation provide a 'snapshot' that can be used to evaluate future changes (Puotinen 1994). Synthesizing these data into products relevant to managers will aid in the selection of informed and achievable objectives (e.g. increasing populations to historical levels, maintaining current ecosystem integrity). These baseline data are important for later steps of assessing the MPA's impacts on marine ecosystems (Dayton et al. 2000, Edgar et al. 2004).

Types of baseline data include: (1) distribution of the key species and habitats that are present, their relative and absolute abundance, as well as their spatial and temporal distributions; (2) characterization of the location, intensity, and seasonality of human uses and threats, and the importance to human communities; and (3) the oceanographic context of the pelagic environment at the time of MPA creation (i.e. currents, fronts, sea temperature).

Due to the highly dynamic nature of the pelagic environment, habitats, species, and oceanographic features may span beyond PMPA boundaries, and the data collected must be considered across a seascape level, not just within the boundaries of the PMPA. Hooker et al. (2011) provide guidance for monitoring highly mobile species and acknowledge that human impacts may similarly need to be monitored beyond PMPA boundaries (e.g. invasive species introduction, shipping, fishing, and pollution, including marine debris). Understanding the wider oceanographic context is also critical, as baseline knowledge of interannual and longer term regimes (i.e. Pacific Decadal Oscillation, regime shifts; Mantua \& Hare 2002) and variables such as sea-surface temperature, upwelling, and primary productivitywhich can serve as proxies for the productivity of foraging resources - can be coupled with future movements and demographics of key protected species inside and outside of the MPAs (Hobday \& Hartmann 2006, Kappes et al. 2010, Hooker et al. 2011).

\section{Tiers of monitoring importance}

The expert solicitation processes described above can be used to determine the key components to be monitored (Martin et al. 2012), and the cost-effectiveness of monitoring can be considered one of the potential management actions when an analysis is undertaken (Carwardine et al. 2012). However, given the difficulties and cost of monitoring dynamic pelagic ecosystems and highly mobile species, we also suggest incorporating a tiered approach for determining the scientific components of monitoring strategies. We suggest expanding monitoring efforts down the tiers with increasing resources. To be optimally cost-effective, however, monitored elements should be chosen because they reflect management objectives and can be used to trigger a management change (Gerber et al. 2005), and cost-effective analyses and SDM can guide the choice of elements.

Tier 1. Threat and socio-economic monitoring

At the most basic level, PMPA managers need to understand human pressures on the PMPA, as most areas are designated to protect an ecosystem or species from current or future threats (Boersma \& Parrish 1999, Agardy 2000, Fox et al. 2012). There are 2 key aspects to understanding human pressures: (1) where and when human activities that threaten aspects of biodiversity occur and (2) how important these activities are to human communities.

First, monitoring human activities allows managers to decide how to allocate scarce resources (e.g. enforcement, outreach, education) to protect the ecological integrity of the system (Sparks et al. 2011). Threat assessment can also highlight baseline data needed to better quantify threats and their impacts on indicator species and habitats (Puotinen 1994). Monitoring the extent of these threats through time can provide a rough approximation of MPA effectiveness.

Second, socio-economic monitoring provides a link between the biological gains of a PMPA and the benefits to local communities. One aspect of socio-economic monitoring is assessing the importance of human activities carried out within the PMPA to human communities, and exploring the concerns and/or expectations of local communities surrounding the PMPA (Marques et al. 2013). Socio-economic monitoring over time can determine how well a PMPA has become integrated into communities, and 
how it is affecting them (positively and negatively). Quantifying socio-economic links is critical and can be done in a variety of ways. For example, metrics that relate the increase in fish populations inside the reserve to increased fish catches outside an MPA are the most obvious examples (Warner \& Pomeroy 2012). Further, understanding how wealth derived from ocean resources is distributed in local communities will aid in understanding the positive and negative impacts of the MPA on individuals through time. This information can be used to understand how incomes are likely to shift given changes in resource management, including which sectors may benefit, or not, and how evenly the wealth will be distributed (Cinner 2007, Pollnac et al. 2010, Ban et al. 2011, White et al. 2013). For remote PMPAs, the user community is often small and diverse. For these places, it might be useful to quantify the 'existence value' of the PMPA to the general public (Stevens et al. 1991). Managers can use this metric to assess whether a user group or wider population knows that the PMPA exists, and to what extent their views of it are favorable. This knowledge can help to structure outreach campaigns, (1) with the goal of increasing awareness for the intrinsic value of the shared PMPA resource and (2) to demonstrate public support in the political arena.

Tier 2. Baseline and indicator species data

Establishing a baseline for the key indicator or protected species and habitats found in a PMPA is a necessary step in evaluating effectiveness. Collecting data on species and habitats, monitoring human uses and threats, and then assimilating these with existing biological and human use data are all components of this baseline evaluation (see 'Baseline data on human use and ecological conditions' above). Managers also need baseline assessments and monitoring to quantify changes through time. These data can be used to determine when and where to focus management efforts and create enforcement strategies, and to assess changes in key populations and habitats through time. A number of relevant model research programs exist for PMPAs, including coral reef and nearshore monitoring that is conducted by NOAA's Coral Reef Ecosystem Division and cetacean monitoring led by NOAA's Pacific Islands Fisheries Science Center (Morgan et al. 2010). Additionally, the US Office of National Marine Sanctuaries developed a simple-to-use, systematic approach for assessing their diverse sites (http://sanctuaries.noaa. gov/science/condition/). Monitoring the reproductive success or foraging ecology of indicator species can determine patterns in the larger ecosystem (Zacharias \& Roff 2001) (Table 2).

Tier 3. Short- and long-term monitoring, demographic responses, and complex ecosystem interactions

Understanding demographic responses of key species and more complex ecosystem responses and interactions to conservation actions often takes long-term monitoring programs and extensive analytical knowledge and techniques. However, shortterm monitoring can also provide valuable information. Short-term population monitoring (i.e. 1 to 5 yr) might be aimed at simply tracking the removal of species by humans either through bycatch, poaching, directed take, or other activities resulting in injury or mortality (e.g. vessel strikes), and relating that to overall population numbers (e.g. demonstrating a $45 \%$ reduction in take between pre-MPA designation and the current monitoring year). For all data collected, monitoring should focus on accuracy, cost-effectiveness, efficiency, and ease of analyses. In contrast, longer term monitoring (i.e. 5 to $15 \mathrm{yr}$ ) should be aimed at more complex studies that can incorporate longterm trends and predictions (e.g. demographic models based on multi-year mark-recapture studies that include human threats (Hooker \& Gerber 2004) and species abundance and distribution modeling (Hooker et al. 2011). Furthermore, these short- and long-term monitoring programs can aid in understanding whether PMPAs are effective in increasing commercial fish abundance, often a key reason for designating them.

Understanding how species and habitats respond to management actions is important for reaching management objectives (Gerber et al. 2011). Collaborating with outside research institutions, such as universities and non-profit organizations, will be the best way to encourage these types of studies, because they often require significant commitments of time and resources. Care should be taken to set up effective collaborations so that external projects address applied management needs (Field et al. 2007). Ultimately, understanding demographic responses and teasing apart complex ecosystem interactions may be the only way to evaluate the longterm effectiveness of the MPA on maintaining or recovering marine life populations. 
Table 2. Example indicator species groups for ecosystem monitoring of pelagic marine protected areas (PMPAs)

\begin{tabular}{|c|c|c|c|}
\hline $\begin{array}{l}\text { Indicator } \\
\text { species group }\end{array}$ & Benefits & Drawbacks & Monitoring techniques \\
\hline \multirow[t]{9}{*}{ Seabirds } & Easily monitored & \multirow{9}{*}{$\begin{array}{l}\text { Range may be well outside of PMPA } \\
\text { May be more sensitive to handling }\end{array}$} & Wet diet for foraging success and available prey \\
\hline & $\begin{array}{l}\text { Tied to breeding sites on land during } \\
\text { breeding season, so reflective of } \\
\text { conditions within foraging range }\end{array}$ & & $\begin{array}{l}\text { Banding studies for survivorship } \\
\text { (mark-recapture) }\end{array}$ \\
\hline & Likely to reflect ecosystem changes: (1) & & \multirow{7}{*}{$\begin{array}{l}\text { Stable isotope for foraging patterns } \\
\text { Chick growth for ecosystem productivity } \\
\text { Satellite tracking for foraging areas and } \\
\text { success }\end{array}$} \\
\hline & chick growth \& survival tightly coupled & & \\
\hline & with short-term ecosystem conditions, (2) & & \\
\hline & $\begin{array}{l}\text { adult survival coupled with longer term } \\
\text { ecosystem conditions }\end{array}$ & & \\
\hline & Distributed over wide ranges & & \\
\hline & Fishery independent data & & \\
\hline & Can sample non-lethally for diet & & \\
\hline \multirow[t]{4}{*}{ Pelagic fishes } & Distributed over wide ranges & $\begin{array}{l}\text { Far-ranging and mobile, so may not be } \\
\text { reflective of local conditions }\end{array}$ & Wet diet for foraging success and available prey \\
\hline & $\begin{array}{l}\text { Highly fecund (mahi-mahi and skipjack), } \\
\text { so reflective of shorter term ecosystem } \\
\text { conditions }\end{array}$ & $\begin{array}{l}\text { Populations may be influenced by } \\
\text { fishing levels, and changes may not be } \\
\text { reflective of ecosystem changes }\end{array}$ & $\begin{array}{l}\text { Conventional tagging studies for survivorship } \\
\text { and movement (mark-recapture) }\end{array}$ \\
\hline & \multirow[t]{2}{*}{$\begin{array}{l}\text { Can potentially partner with commercial } \\
\text { fisheries to monitor }\end{array}$} & \multirow[t]{2}{*}{ Need at-sea studies to monitor } & $\begin{array}{l}\text { Stable isotope for foraging patterns } \\
\text { Satellite tracking for foraging areas and } \\
\text { success }\end{array}$ \\
\hline & & & Fishery-dependent studies \\
\hline \multirow[t]{4}{*}{ Cetaceans } & Distributed over wide ranges & $\begin{array}{l}\text { Far-ranging and mobile, so may not be } \\
\text { reflective of local conditions }\end{array}$ & $\begin{array}{l}\text { Conventional tagging, photo-identification, or } \\
\text { genetic studies for survivorship and movement } \\
\text { (mark-recapture) }\end{array}$ \\
\hline & $\begin{array}{l}\text { Often protected species; may be a key } \\
\text { species for PMPA establishment }\end{array}$ & Need at-sea studies to monitor & Stable isotope for foraging patterns \\
\hline & \multirow{2}{*}{$\begin{array}{l}\text { Migratory species may have smaller } \\
\text { breeding/foraging areas that are } \\
\text { critically important for life-history and } \\
\text { population trends (large expected effect } \\
\text { size with protection) }\end{array}$} & Diet studies difficult & $\begin{array}{l}\text { Satellite tracking for foraging areas and } \\
\text { success }\end{array}$ \\
\hline & & $\begin{array}{l}\text { Range may be well outside of PMPA } \\
\text { boundaries }\end{array}$ & Surveys to monitor trends in abundance \\
\hline \multirow[t]{5}{*}{ Sea turtles } & $\begin{array}{l}\text { Come to breeding sites on land to nest } \\
\text { and can be monitored then }\end{array}$ & $\begin{array}{l}\text { May be far-ranging and mobile, so may } \\
\text { not be reflective of local conditions }\end{array}$ & Wet diet for foraging success and available prey \\
\hline & $\begin{array}{l}\text { Some species feed locally, so can be } \\
\text { reflective of local conditions }\end{array}$ & \multirow{4}{*}{$\begin{array}{l}\text { Range may be well outside of PMPA } \\
\text { boundaries }\end{array}$} & $\begin{array}{l}\text { Conventional tagging or genetic studies for } \\
\text { survivorship and movement (mark-recapture) }\end{array}$ \\
\hline & Some species distributed over wide ranges & & Stable isotope for foraging patterns \\
\hline & $\begin{array}{l}\text { Migratory species may have smaller } \\
\text { breeding/foraging areas that are }\end{array}$ & & $\begin{array}{l}\text { Satellite tracking for foraging areas and } \\
\text { success }\end{array}$ \\
\hline & $\begin{array}{l}\text { critically important for life-history and } \\
\text { population trends (large expected effect } \\
\text { size with protection) }\end{array}$ & & $\begin{array}{l}\text { Aerial surveys and beach monitoring for } \\
\text { population levels during nesting and mating } \\
\text { seasons }\end{array}$ \\
\hline
\end{tabular}

\section{COMPLIANCE AND ENFORCEMENT WITHIN PMPAS}

While compliance and enforcement are issues for all MPAs (Walmsley \& White 2003, Byers \& Noonburg 2007, Samoilys et al. 2007), they represent some of the limiting factors cited for managing PMPAs in particular (Kaplan et al. 2010). Enforcement of PMPAs can be particularly challenging because of the large and often remote areas to be monitored and the cost of reaching these areas, either by boat or aircraft, as well as the disparate stakeholder groups and communities associated with such areas. While we make suggestions below, cost-effectiveness approaches that explicitly include stakeholders can be powerful in helping to determine the best approaches for compliance and enforcement for individual PMPAs (see 'Cost-effective approaches' above). Furthermore, by including compliance and enforcement in the cost-effectiveness analysis, they can be compared to, and prioritized with, other management actions.

\section{Outreach and education}

Targeted outreach and education may achieve better compliance than relying heavily on enforcement. Numerous studies have highlighted that compliance is best achieved via community consul- 
tations, conflict management mechanisms, education or capacity building, and accountable and participatory management (Pollnac 2010, Read et al. 2011, Warner \& Pomeroy 2012, Miller et al. 2013). However, Warner \& Pomeroy (2012) showed that the influence of 'goodwill activities' on compliance can vary markedly depending on the type of community to which MPAs are adjacent. For example, with capacity building, alternative livelihood programs and other activities significantly increased compliance in traditional fishing communities, but had a negative influence on MPAs near communities where tourism and other industries besides fishing were the primary economic sources. Additionally, when activities were implemented in the MPA planning and implementation process resulted in differences in how activities influenced MPA compliance. These kinds of nuanced views are important to consider for PMPAs, as communities are likely to be numerous and disparate, both in spatial use and activities; thus, documenting the influence of similar variables on compliance will be important to guide development of future PMPAs.

\section{Participatory compliance and enforcement}

One way to enhance compliance is by engaging users and stakeholders directly in compliance activities through 'participatory monitoring' (Aswani \& Weiant 2004, Danielsen et al. 2009, Fox et al. 2012). Involving PMPA users and stakeholders in the surveillance and enforcement process can help increase capacity, inform users about the regulations, increase public perception of legitimacy of the regulations, build collective understanding of enforcement needs, and reduce costs to enforcement agencies.

Peer reporting is one example of participatory monitoring already being carried out within an existing PMPA. The Phoenix Islands Protected Area requires that boats report to multiple agencies: (1) when they enter the MPA and (2) whenever they see another vessel (Phoenix Islands Protected Area 2010). This allows enforcement agencies to keep track of vessels entering the MPA and to know which ones are following regulations by pairing boat sightings. This method is particularly useful in remote PMPAs where the potential for infractions is high because the chance of encounter by government vessels is low. Participatory monitoring increases the number of 'eyes on the water' and allows government agencies to better target use of enforcement vessels.

\section{Enforcement}

PMPAs will likely require significant enforcement efforts because stakeholders will be disparate and logistically difficult to interact with, and the remoteness of areas increases the potential for illegal, unreported, and unregulated fishing, as well as other detrimental activities. Theoretically, however, the larger an MPA is, the more ecologically effective it will be even with limited enforcement because edge effects (encroachment along the MPA boundaries by humans affecting species inside the protected area) are less problematic for large areas with greater center to edge ratios than for small ones, and because vessels must enter MPAs through the edges (Kritzer 2004, Le Quesne 2009). Still, cost-effective methods of enforcement and monitoring are important for the long-term viability of a PMPA. Below we focus on specific techniques for cost-effective monitoring.

\section{Enforcement partnerships}

Enforcement partnerships can aid cost-effectiveness. For example, the US Coast Guard (USCG) has initiated partnerships with the US Navy and foreign national fishery enforcement authorities as 'force multipliers' to improve its maritime domain awareness. The USCG has shiprider agreements with the US Navy, whereby USCG Liaison Officers are placed on board Navy vessels transiting the Pacific. The USCG officer can use the Navy vessel as an observation platform to complement data provided by the USCG operations center to track and document fishing vessel activity. The USCG and Navy are also working on an arrangement that would allow USCG law enforcement boarding teams to travel on Navy ships, which would not only allow the USCG to document illegally activity, but also to actually interdict vessels.

The USCG has also developed shiprider agreements with Pacific Island Nations that border United States island exclusive economic zones (EEZs), allowing the 9 nations (USA, Kiribati, Cook Islands, Marshall Islands, Micronesia, Nauru, Palau, Tonga, and Tuvalu) to conduct joint enforcement exercises. When in a foreign nation's EEZ, the USCG will carry a foreign law enforcement official, allowing increased enforcement of the foreign nation's EEZ. During these bilateral patrols, the USCG also has access to the foreign nations' vessel monitoring systems of boats inside their EEZs. In the case of Kiribati or 
other nations that share an EEZ boundary with the USA, this access provides the USCG and NOAA with real-time visibility of fishing vessel activity on both sides of the US border. These bilateral exercises are vital to providing additional visibility in the maritime domain, but are infrequent.

\section{Technologies for monitoring vessels}

A number of technologies for monitoring vessel activity now exist, including cooperative and noncooperative systems (Brooke et al. 2010) (Table 3). Cooperative systems are those in which only partic-

Table 3. Emerging or in-use surveillance and enforcement technologies for pelagic marine protected areas (PMPAs) (adapted from Richardson 2012 and Brooke et al. 2010). We recommend that the reader should refer to these 2 freely available reports for more information

\begin{tabular}{|c|c|c|c|c|}
\hline Technology & $\begin{array}{l}\text { Emerging or } \\
\text { in-use }\end{array}$ & Description & Potential drawbacks & Specific application to PMPAs \\
\hline \multicolumn{5}{|l|}{ Cooperative systems } \\
\hline $\begin{array}{l}\text { Vessel Monitoring } \\
\text { Systems (VMS) }\end{array}$ & In-use & $\begin{array}{l}\text { Allow for monitoring of vessels within } \\
\text { boundaries; can determine activity } \\
\text { of vessels based on behavior }\end{array}$ & $\begin{array}{l}\text { Vessels must agree to carry VMS } \\
\text { equipment; cannot be used to monitor } \\
\text { non-cooperative vessels; units are } \\
\text { costly (US\$1000-4000 each); often } \\
\text { potential violations detected by VMS } \\
\text { must be corroborated by direct } \\
\text { observation }\end{array}$ & $\begin{array}{l}\text { Useful for monitoring vessel activity } \\
\text { in remote areas common in PMPAs }\end{array}$ \\
\hline $\begin{array}{l}\text { Automatic } \\
\text { Identification } \\
\text { Systems (AIS) }\end{array}$ & In-use & $\begin{array}{l}\text { Broadcast system that transmits data } \\
\text { such as location, speed, and heading; } \\
\text { can be detected by other vessels and } \\
\text { authorities, within a limited range } \\
\text { (20-100 nmi); space-based } \\
\text { AIS which uses satellite technology } \\
\text { increases the coverage to } 5000 \mathrm{~km}\end{array}$ & $\begin{array}{l}\text { Spatial or temporal coverage may be } \\
\text { limited; vessels must agree to carry } \\
\text { equipment }\end{array}$ & $\begin{array}{l}\text { Use is required by merchant ships } \\
\text { over } 300 \text { gross tons by international } \\
\text { law }\end{array}$ \\
\hline \multicolumn{5}{|c|}{ Non-cooperative systems } \\
\hline $\begin{array}{l}\text { Predictive soft- } \\
\text { ware programs } \\
\text { for fishing } \\
\text { activity } \\
\text { (e.g. Sea Star) }\end{array}$ & In-use & $\begin{array}{l}\text { Commercial products that use oceano- } \\
\text { graphic and biological data to predict } \\
\text { where fishing 'hotspots' are likely to } \\
\text { occur, so enforcement can be targeted } \\
\text { where vessels are likely to be } \\
\text { encountered }\end{array}$ & $\begin{array}{l}\text { Must pay for access to products, which } \\
\text { can be costly }\end{array}$ & $\begin{array}{l}\text { Already used by the US Coast Guard } \\
\text { in the Pacific; can narrow down } \\
\text { where in large pelagic habitats } \\
\text { fishing is likely to occur }\end{array}$ \\
\hline Radar & In-use & $\begin{array}{l}\text { Radio waves detect reflections from } \\
\text { objects in their path such as vessels; } \\
\text { new technologies such as over-the- } \\
\text { horizon radar and high-frequency } \\
\text { surface wave radar allow for detection } \\
\text { on the scale of 1000s of kilometers }\end{array}$ & $\begin{array}{l}\text { Identification of individual vessels is } \\
\text { not feasible, so must be used in } \\
\text { conjunction with other monitoring } \\
\text { platforms }\end{array}$ & $\begin{array}{l}\text { Can be used in remote settings; lower } \\
\text { costs than vessel-based monitoring }\end{array}$ \\
\hline $\begin{array}{l}\text { Space-based } \\
\text { synthetic aperture } \\
\text { radar (SAR) and } \\
\text { optical imagery }\end{array}$ & In-use & $\begin{array}{l}\text { Allows for detection of vessels using } \\
\text { satellite-based technology in near } \\
\text { real-time. At resolutions of } 1.6 \mathrm{~m}, \\
\text { optical imagery can identify } \\
\text { individual vessels }\end{array}$ & $\begin{array}{l}\text { SAR cannot identify vessels at an indi- } \\
\text { vidual scale, but can be used at night } \\
\text { and in cloudy areas. Optical imagery } \\
\text { is limited by cloud cover and } \\
\text { nighttime. Both services are costly }\end{array}$ & $\begin{array}{l}\text { While services are costly, they may be } \\
\text { cheaper than vessel-based } \\
\text { monitoring }\end{array}$ \\
\hline $\begin{array}{l}\text { Passive acoustic } \\
\text { monitoring }\end{array}$ & $\begin{array}{l}\text { In-use/ } \\
\text { emerging }\end{array}$ & $\begin{array}{l}\text { Can be used for detection of vessel } \\
\text { noise and certain activities with } \\
\text { distinct noise patterns. Use of vessel } \\
\text { arrays tied to a land mass can transmit } \\
\text { data in near real-time. Depending on } \\
\text { equipment, can be used for detection } \\
\text { over 1000s of kilometers. Autonomous } \\
\text { buoys can transmit data remotely }\end{array}$ & $\begin{array}{l}\text { Fiber-optic cables are necessary to } \\
\text { connect to land and may limit appli- } \\
\text { cation far from land. Autonomous } \\
\text { buoys exist, but are limited by battery } \\
\text { power and maintenance. Identification } \\
\text { of individual vessels is not feasible, so } \\
\text { they must be used in conjunction with } \\
\text { other monitoring platforms }\end{array}$ & $\begin{array}{l}\text { Using vessel noise may be a cost- } \\
\text { effective option for monitoring in } \\
\text { remote areas }\end{array}$ \\
\hline $\begin{array}{l}\text { Autonomous water } \\
\text { or aerial vehicles }\end{array}$ & Emerging & $\begin{array}{l}\text { Autonomous vehicles can be used } \\
\text { either in the air or underwater to } \\
\text { monitor areas }\end{array}$ & $\begin{array}{l}\text { Autonomous vehicles can be extremely } \\
\text { costly and, currently, are only avail- } \\
\text { able for military applications. } \\
\text { Underwater vehicles must be pre- } \\
\text { programmed due to a lack of real-time } \\
\text { data feeds (i.e. unable to connect to } \\
\text { satellites under water) }\end{array}$ & $\begin{array}{l}\text { As technology develops and costs are } \\
\text { reduced, autonomous vehicles may } \\
\text { be a primary means of monitoring } \\
\text { and surveillance }\end{array}$ \\
\hline $\begin{array}{l}\text { Surface or under- } \\
\text { water gliders }\end{array}$ & Emerging & $\begin{array}{l}\text { Small autonomous vehicles designed } \\
\text { to collect data on ocean conditions. } \\
\text { Are commercially available and are } \\
\text { inexpensive compared to other } \\
\text { autonomous vehicles; surface gliders } \\
\text { are capable of operating for over } \\
400 \text { d before maintenance }\end{array}$ & $\begin{array}{l}\text { Underwater gliders are particularly } \\
\text { limited by battery power because } \\
\text { they cannot be solar powered. Have } \\
\text { yet to be used for monitoring of } \\
\text { vessels; current applications target } \\
\text { oceanographic and biological } \\
\text { monitoring }\end{array}$ & $\begin{array}{l}\text { Cost and marketability make gliders } \\
\text { a potentially cost-effective option for } \\
\text { PMPAs in the near future }\end{array}$ \\
\hline
\end{tabular}


ipating vessels are monitored; the best example for use in PMPAs are vessel monitoring systems (VMS), which can only observe those vessels that cooperate by carrying transceivers. Although cooperative in nature, there is usually a legal requirement for participation in VMS systems, such that some vessels may participate unwillingly and might interfere with onboard surveillance systems. VMS may not be cost-effective in developing countries, particularly for artisanal fisheries, and their range may be limited to coastal areas of PMPAs. Additionally, inferring the type of activity that is occurring based only on speed and location can be challenging, but, for example, has been done effectively in the United Kingdom (Witt \& Godley 2007). More complex methods such as state-space models have been used to determine different modes of fishing activity in tuna purse seine fisheries (Bez et al. 2011). The level of information provided by cooperative systems makes them a valuable surveillance tool.

A number of non-cooperative technologies are also available to monitor activities (Table 3). For example, aerial flights or passive acoustic monitoring arrays can be used for a number of human threats. Low-frequency noise is indicative of boats, higher frequency noise is indicative of sonar. These methods could be particularly useful in remote PMPAs where limited boat-based activity is expected, though they have yet to be applied to our knowledge. Monitoring arrays could also double as monitors for ecological components by incorporating business-card or acoustic tags to survey species' movements and distributions (Hayes et al. 2013). A wide variety of satellite systems are also available to monitor vessels and activities remotely (e.g. Brooke et al. 2010, Richardson 2012). Increasing interest in remotely operated drones and other similar technologies is leading to significant and rapid progress in this field (Brooke et al. 2010, Richardson 2012).

\section{Measures to avoid entering MPAs}

In some instances, the easiest way to prevent unwanted human activities is to provide disincentives for entering a PMPA. For example, Papahānaumokuākea MNM has been designated a Particularly Sensitive Sea Area (PSSA) by the International Maritime Organization (IMO). A PSSA

... is an area that needs special protection through action by the IMO because of its significance for recognized ecological, socio-economic or scientific reasons and which may be vulnerable to damage by international maritime activities (IMO Resolution A.982[24])

To enter Papahānaumokuākea MNM, vessels must request permission to pass through the monument. The number of vessels in the monument has dropped precipitously, presumably because requesting permission requires more effort than simply avoiding the PSSA (A. Wilhelm pers. comm.). Similarly, requiring a VMS in order to enter a PMPA may also provide a disincentive and make enforcement easier, as any vessel without a VMS is in violation, regardless of activity.

\section{Biological and enforcement priorities}

Management and enforcement of any MPA requires the setting of priorities, but, because of their large size, this step is even more critical for PMPAs. Ideally, all areas should be fully monitored and enforced; however, this is rarely logistically or financially possible. As a result, managers need to determine where and when management resources and enforcement efforts are needed most, and concentrate efforts on those times and places. Again, the cost-effectiveness and expert solicitation techniques described above can be used to help determine these priorities, as well as the enforcement actions that should accompany priorities (Martin et al. 2009, Carwardine et al. 2012). Also important in setting priorities is linking actions, budgets, and agencies together by (1) defining biological priorities (i.e. species or areas of management concern) and (2) linking these to enforcement priorities (Fig. 3).

\section{Biological priorities}

Though PMPA objectives may vary, maintenance of the ecological system and protection of vulnerable species are common priorities. Establishing biological priorities for monitoring and enforcement means determining where the most vulnerable species or habitats are likely to be found and when they are most vulnerable. Biological prioritization is built from baseline data of key species and habitats, as well as human uses and impacts (see 'Baseline data on human use and ecological conditions'). However, integrating key species and habitat data with human use and impact data will determine where the regions of highest threat and ecological significance co-occur (Halpern et al. 2009, Maxwell et al. 2013). In this step it is particularly important to consider where 
these areas occur temporally, as well as spatially. Pelagic species often have seasonal movements, so impacts may be seasonal as well. Illegal fishing, for example, may not always coincide with peaks in fish abundance. For example, fishermen may be more likely to fish illegally during times of the year when they need income the most (i.e. during holidays), and these times may not be the most biologically productive times of the year. The temporal component and the social drivers underlying human use are particularly important for determining enforcement priorities (detailed below). Understanding the spatio-temporal patterns of threats can help enforcers target illegal activity before it occurs.

\section{Enforcement priorities}

Enforcement priorities stem from translating biological priorities into actions for enforcement agencies (Fig. 3). Enforcement agencies are often charged with a myriad of activities to monitor and enforce, and a reality of modern governing structures is that all areas cannot be adequately enforced at all times. The USCG exemplifies an agency with multiple mandates in homeland security, fisheries, and search and rescue, to name a few. Enforcement officers will often concentrate efforts on well-articulated problems for which they feel they will have an impact

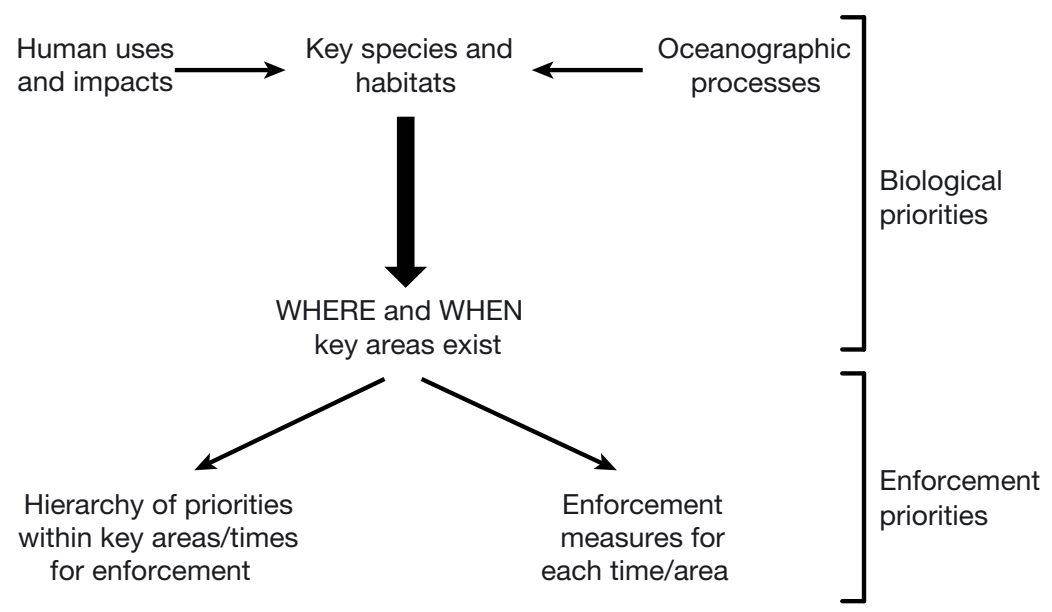

Fig. 3. Schematic showing the translation of biological priorities to enforcement priorities. In addition to understanding the distribution of key species and habitats, it may be important to integrate how oceanographic processes drive or dictate these areas, as well as how human uses and impacts overlap with key species and habitats. Once the 'where and when' of these areas has been determined, a hierarchy of priorities for enforcement for each key area must be determined to facilitate effective enforcement in that area. Additionally, the type and level of enforcement necessary for each area should be indicated (e.g. frequent patrolling for highly sensitive habitats or occasional fly-overs of largescale, less sensitive habitats)
(Gregg Casad, USCG, pers. comm.). Providing such well-articulated priorities for enforcement is essential for MPA managers. Ways to do this include:

(1) Translating biological priorities into enforcement priorities. Biological priorities do not translate directly into enforcement priorities. For example, a map detailing the $25,50,75$, and $100 \%$ habitat use contours for a protected species does not indicate to an enforcement agent where to concentrate effort. Does the $50 \%$ contour or the $25 \%$ contour contain the most critical habitat? What if the $25 \%$ contour includes $5000 \mathrm{~km}^{2}$ of pelagic habitat; can that area be further prioritized? Does the same apply for September as for March, or are there months or seasons when enforcement is more critical than others? Appropriate surveillance and enforcement involves distilling spatial and temporal biological priorities into maps and tables which clearly detail the places and times where enforcement is most critical-and includes a hierarchy of priorities among the key sites. This ensures the maximum efficiency of enforcement efforts. For example, within PRIMNM, managers may provide enforcement agencies with a map of 10 key areas, with associated information on the months when these areas are most heavily used by species most vulnerable to human impacts. They may also list places that correspond to key vulnerable habitats - in order of importance - that are most critical to enforce during the different months of the year. This will allow enforcement agencies to apply resources when they are available, and also to plan enforcement missions opportunistically as part of other work.

Relevant oceanographic data can also be critical for integrating biological and management priorities. For example, to further leverage its limited air and sea assets, the USCG uses 'SeaStar', a commercial oceanographic mapping software that combines remote sensing data, target species biology, and computer algorithms to identify potential fishing hotspots for US and foreign commercial fishing fleets. By using this software, Coast Guard personnel can anticipate fish locations, and therefore where they are most likely to encounter fishing activity, both legal and illegal.

(2) Determining effective enforcement measures. Different species and habitats will require different protec- 
tion and enforcement measures. For example, protecting seabirds from bycatch in longline fisheries may require enforcing use of streamer lines on fishing vessels, while protecting deep-sea corals from fishing impacts may require ensuring bottom trawling bans are enforced within a PMPA's boundaries. Highlighting the most effective enforcement measures and prioritizing among the measures to the extent possible for different biological components will allow enforcement agencies to determine appropriate actions. For instance, frequent boat-based enforcement actions aimed at reducing illegal bottom trawling activity might be needed in a highly sensitive deep-sea coral area, while occasional flyovers of a less sensitive region might be sufficient to help managers track a wide variety of activities.

\section{CONCLUSIONS}

Our understanding of how to effectively manage PMPAs, particularly in remote parts of the world (Fig. 1), is only beginning to develop. Most MPAs with large pelagic areas have been designated in the last $15 \mathrm{yr}$, and the management objectives of earlier MPAs were primarily focused on nearshore ecosystems, not on pelagic ecosystems. Thus, an emerging goal is to move towards managing areas based on the underlying dynamic environment, and the dynamic nature of the human activities that impact PMPAs (Game et al. 2009, Grantham et al. 2011, Maxwell et al. 2012, Hobday et al. 2014). In the meantime, as managers accumulate knowledge and experience managing PMPAs, we hope that the information above will serve as a foundation for collating this knowledge, particularly though the Big Ocean Network (Toonen et al. 2013). Furthermore, by providing insights into the practical realities of PMPA management, we hope that we have highlighted critical research arenas and knowledge gaps of maximum relevance for MPA managers.

Acknowledgements. We thank the participants of the Marine Think Tank session on 'Pelagic ecosystems and MPA management' held as part of the 2011 International Congress on Conservation Biology in Auckland: J. Ardron, N. Agular Soto, J. Armstrong, M. Beritzhoff, C. Boyd, R. Brock, J. Cigliano, B. Hartl, L. Kozmian-Ledward, P. K. Mulcahy, Liza Mustika, M. Palka, J. Sterling, J. Zaeschmar. We thank the members of the Big Ocean Network, particularly A. Wilheim, S. Tai, C. Sheppard, A. Sheppard, R. Toonen, and B. Bowen, as well as G. Notarbartolo-Di-Sciara, for discussions and insight into managing PMPAs. We are grateful to staff of the National Marine Fisheries Service, including H. Hirsh and E. Breur; the Marine Conservation Institute, especially B. Pike, R. Moffitt, B. Chandler, and M. Richardson; and
TWIG for insights and comments. This work was supported by a grant from the National Oceanic and Atmospheric Administration (NA10NMF429028).

\section{LITERATURE CITED}

Agardy T (2000) Information needs for marine protected areas: scientific and societal. Bull Mar Sci 66:875-888

- Alpine JE, Hobday AJ (2007) Area requirements and pelagic protected areas: Is size an impediment to implementation? Mar Freshw Res 58:558-569

Angel MV (1993) Biodiversity of the pelagic ocean. Conserv Biol 7:760-772

> Ardron J, Gjerde K, Pullen S, Tilot V (2008) Marine spatial planning in the high seas. Mar Policy 32:832-839

Aswani S, Weiant P (2004) Scientific evaluation in women's participatory management: monitoring marine invertebrate refugia in the Solomon Islands. Hum Organ 63:301-319

$>$ Ban NC, Alidina HM, Ardron JA (2010) Cumulative impact mapping: advances, relevance and limitations to marine management and conservation, using Canada's Pacific waters as a case study. Mar Policy 34:876-886

- Ban NC, Adams VM, Almany GR, Ban S and others (2011) Designing, implementing and managing marine protected areas: emerging trends and opportunities for coral reef nations. J Exp Mar Biol Ecol 408:21-31

Ban NC, Maxwell SM, Dunn D, Hobday AJ and others (2014a) Better integration of sectoral planning and management approaches for the interlinked ecology of the open oceans. Mar Policy 49:127-136

Ban NC, Bax NJ, Gjerde KM, Devillers R and others (2014b) Systematic conservation planning: a better recipe for managing the high seas for biodiversity conservation and sustainable use. Conserv Lett 7:41-54

- Bez N, Walker E, Gaertner D, Rivoirard J, Gaspar P (2011) Fishing activity of tuna purse seiners estimated from vessel monitoring system (VMS) data. Can J Fish Aquat Sci 68:1998-2010

> Boersma PD, Parrish JK (1999) Limiting abuse: marine protected areas, a limited solution. Ecol Econ 31:287-304

- Brauers WKM, Zavadskas EK, Peldschus F, Turskis Z (2008) Multi-objective decision-making for road design. Transport 23:183-193

Brooke SD, Lim TY, Ardron JA (2010) Surveillance and enforcement of remote maritime areas. Paper 1: surveillance technical options. Marine Conservation Biology Institute, Bellevue, WA

Byers JE, Noonburg EG (2007) Poaching, enforcement, and the efficacy of marine reserves. Ecol Appl 17:1851-1856

> Carwardine J, O'Connor T, Legge S, Mackey B, Possingham HP, Martin TG (2012) Prioritizing threat management for biodiversity conservation. Conserv Lett 5:196-204

Cinner JE (2007) Designing marine reserves to reflect local socioeconomic conditions: lessons from long-enduring customary management systems. Coral Reefs 26: 1035-1045

Convention on Biological Diversity (2010) The strategic plan for biodiversity 2011-2020 and the Aichi biodiversity targets. In: Conference of Parties 10, Decision X/2, Strategic Plan for Biodiversity 2011-2020. p 111-123. Tenth meeting of the Conferenceof the Parties to the Convention on Biological Diversity, Nagoya, Japan, 18-29 October 2010, www.cbd.int/doc/decisions/cop-10/ full/cop-10-dec-en.pdf 
Costello C, Gaines SD, Lynham J (2008) Can catch shares prevent fisheries collapse? Science 321:1678-1681

Costello C, Lynham J, Lester SE, Gaines SD (2010) Economic incentives and global fisheries sustainability. Annu Rev Resour Econ 2, p 299-318

Danielsen F, Burgess ND, Balmford A, Donald PF and others (2009) Local participation in natural resource monitoring: a characterization of approaches. Conserv Biol 23:31-42

Dayton PK, Sala E, Tegner MJ, Thrush S (2000) Marine reserves: parks, baselines, and fishery enhancement. Bull Mar Sci 66:617-634

> Dichmont CM, Pascoe S, Jebreen E, Pears R, Brooks K, Perez P (2013) Choosing a fishery's governance structure using data poor methods. Mar Policy 37:123-131

> Edgar GJ, Bustamante RH, Farina JM, Calvopina M, Martinez C, Toral-Granda MV (2004) Bias in evaluating the effects of marine protected areas: the importance of baseline data for the Galapagos Marine Reserve. Environ Conserv 31:212-218

Espinosa-Romero MJ, Chan KMA, McDaniels T, Dalmer DM (2011) Structuring decision-making for ecosystembased management. Mar Policy 35:575-583

> Field SA, O'Connor PJ, Tyre AJ, Possingham HP (2007) Making monitoring meaningful. Austral Ecol 32:485-491

> Fox HE, Mascia MB, Basurto X, Costa A and others (2012) Reexamining the science of marine protected areas: linking knowledge to action. Conserv Lett 5:1-10

> Gaines SD, Lester SE, Grorud-Colvert K, Costello C, Pollnac $R$ (2010) Evolving science of marine reserves: new developments and emerging research frontiers. Proc Natl Acad Sci USA 107:18251-18255

Game ET, Grantham HS, Hobday AJ, Pressey RL and others (2009) Pelagic protected areas: the missing dimension in ocean conservation. Trends Ecol Evol 24:360-369

Gerber LR, Beger M, McCarthy MA, Possingham HP (2005) A theory for optimal monitoring of marine reserves. Ecol Lett 8:829-837

> Gerber LR, Estes J, Crawford TG, Peavey LE, Read AJ (2011) Managing for extinction? Conflicting conservation objectives in a large marine reserve. Conserv Lett 4: 417-422

> Grantham HS, Game ET, Lombard AT, Hobday AJ and others (2011) Accommodating dynamic oceanographic processes and pelagic biodiversity in marine conservation planning. PLoS ONE 6:e16552

> Grech A, Marsh H (2008) Rapid assessment of risks to a mobile marine mammal in an ecosystem-scale marine protected area. Conserv Biol 22:711-720

Halpern BS, McLeod KL, Rosenberg AA, Crowder LB (2008) Managing for cumulative impacts in ecosystem-based management through ocean zoning. Ocean Coast Manage 51:203-211

Halpern BS, Kappel CV, Selkoe KA, Micheli F and others (2009) Mapping cumulative human impacts to California Current marine ecosystems. Conserv Lett 2:138-148

> Hayes SA, Teutschel NM, Michel CJ, Champagne C and others (2013) Mobile receivers: releasing the mooring to 'see' where fish go. Environ Biol Fishes 96:189-201

Hobday AJ, Hartmann K (2006) Near real-time spatial management based on habitat predictions for a longline bycatch species. Fish Manag Ecol 13:365-380

Hobday AJ, Maxwell SM, Forgie J, McDonald J and others (2014) Dynamic ocean management: integrating scientific and technological capacity with law, policy and management. Stanford Environ Law J 33:125-165
Hocking M, Stolton S, Dudley N (2000) Evaluating effectiveness: a framework for assessing the management of protected areas, IUCN, Gland

- Hooker SK, Gerber LR (2004) Marine reserves as a tool for ecosystem-based management: the potential importance of megafauna. Bioscience 54:27-39

> Hooker S, Cañadas A, Hyrenbach KD, Corrigan C, Polovina J, Reeves RR (2011) Making protected area networks effective for marine top predators. Endang Species Res 13:203-218

Hyrenbach KD, Forney KA, Dayton P (2000) Marine protected areas and ocean basin management. Aquat Conserv 10:437-458

- Irwin BJ, Wilberg MJ, Jones ML, Bence JR (2011) Applying structured decision making to recreational fisheries management. Fisheries 36:113-122

- Kaplan DM, Chassot E, Gruss A, Fonteneau A (2010) Pelagic MPAS: The devil is in the details. Trends Ecol Evol 25: 62-63

Kappes MA, Shaffer SA, Tremblay Y, Foley DG and others (2010) Hawaiian albatrosses track interannual variability of marine habitats in the North Pacific. Prog Oceanogr 86:246-260

Kritzer JP (2004) Effects of noncompliance on the success of alternative designs of marine protected-area networks for conservation and fisheries management. Conserv Biol 18:1021-1031

> Le Quesne WJF (2009) Are flawed MPAS any good or just a new way of making old mistakes? ICES J Mar Sci 66: 132-136

> Lowry LF, Laist DW, Gilmartin WG, Antonelis GA (2011) Recovery of the Hawaiian monk seal (Monachus schauinslandi): a review of conservation efforts, 1972 to 2010, and thoughts for the future. Aquat Mamm 37:397-419

Mantua NJ, Hare SR (2002) The Pacific decadal oscillation. J Oceanogr 58:35-44

Marcot BG, Thompson MP, Runge MC, Thompson FR and others (2012) Recent advances in applying decision science to managing national forests. For Ecol Manage 285: $123-132$

> Marques AS, Ramos TB, Caeiro S, Costa MH (2013) Adaptive-participative sustainability indicators in marine protected areas: design and communication. Ocean Coast Manage 72:36-45

> Martin J, Runge MC, Nichols JD, Lubow BC, Kendall WL (2009) Structured decision making as a conceptual framework to identify thresholds for conservation and management. Ecol Appl 19:1079-1090

Martin TG, Burgman MA, Fidler F, Kuhnert PM, Low-Choy S, McBride M, Mengersen K (2012) Eliciting expert knowledge in conservation science. Conserv Biol 26: 29-38

Maxwell SM, Morgan LE (2012) Examination of pelagic marine protected area management with recommendations for the Pacific Remote Islands Marine National Monument. Marine Conservation Institute, Seattle, WA

Maxwell SM, Morgan LE (2013) Foraging of seabirds on pelagic fishes: implications for management of pelagic marine protected areas. Mar Ecol Prog Ser 481:289-303

Maxwell SM, Hazen EL, Morgan LE, Bailey H, Lewison R (2012) Finding balance in fisheries management. Science 336:413

> Maxwell SM, Hazen EL, Bograd SJ, Halpern BS and others (2013) Cumulative human impacts on marine predators. Nat Commun 4 (2688): 1-9) 
McCrea-Strub A, Zeller D, Sumaila UR, Nelson J, Balmford A, Pauly D (2011) Understanding the cost of establishing marine protected areas. Mar Policy 35:1-9

McDonald-Madden E, Baxter PWJ, Fuller RA, Martin TG, Game ET, Montambault J, Possingham HP (2010) Monitoring does not always count. Trends Ecol Evol 25: 547-550

McGowan CP (2013) A structured approach to incidental take decision making. Environ Manage 51:241-250

Miller DGM, Slicer NM, Hanich Q (2013) Monitoring, control and surveillance of protected areas and specially managed areas in the marine domain. Mar Policy 39: $64-71$

Morgan LE, Chandler W, Douce E, Brooke S, Guinotte J, Myhre S (2010) Research priorities for the Pacific Remote Islands Marine National Monument. Marine Conservation Biology Institute, Bellevue, WA

Norse E (2005) Pelagic protected areas: the greatest parks challenge of the $21^{\text {st }}$ century. Parks 15:1-9. http://mcbi. marine-conservation.org/publications/pub_pdfs/Norse_ parks_2005.pdf

> Notarbartolo-Di-Sciara G, Agardy T, Hyrenbach D, Scovazzi T, Van Klaveren P (2008) The pelagos sanctuary for Mediterranean marine mammals. Aquat Conserv 18: 367-391

Phoenix Islands Protected Area (2010) Phoenix Islands protected area management plan, 2010-2014, Kiribati Ministry of Environment, Lands \& Agricultural Development, Tarawa

Pollnac R, Christie P, Cinner JTD and others (2010) Marine reserves as linked social-ecological systems. Proc Natl Acad Sci USA 107 (43):18262-18265

Pomeroy RS, Parks JE, Watson LM (2004) How is your MPA doing? A guidebook of natural and social indicators for evaluating marine protected area management effectiveness. IUCN, Gland

Pressey RL, Bottrill MC (2009) Approaches to landscapeand seascape-scale conservation planning: convergence, contrasts and challenges. Oryx 43:464-475

Puotinen ML (1994) Designing effective base-line monitoring programs for the Great Barrier Reef Marine Park, Queensland, Australia. Coast Manage 22:391-398

Read AD, West RJ, Haste M, Jordan A (2011) Optimizing voluntary compliance in marine protected areas: a comparison of recreational fisher and enforcement officer perspectives using multi-criteria analysis. J Environ Manage 92:2558-2567

Richardson M (2012) Protecting America's Pacific marine

Editorial responsibility: Nicholas Tolimieri,

Seattle, Washington, USA monuments: a review of threats and law enforcement issues. Marine Conservation Institute, Washington, DC

Samoilys MA, Martin-Smith KM, Giles BG, Cabrera B, Anticamara JA, Brunio EO, Vincent ACJ (2007) Effectiveness of five small Philippines' coral reef reserves for fish populations depends on site-specific factors, particularly enforcement history. Biol Conserv 136:584-601

Sowman M, Hauck M, van Sittert L, Sunde J (2011) Marine protected area management in South Africa: new policies, old paradigms. Environ Manage 47:573-583

Sparks TH, Butchart SHM, Balmford A, Bennun L and others (2011) Linked indicator sets for addressing biodiversity loss. Oryx 45:411-419

Stevens TH, Echeverria J, Glass RJ, Hager T, More TA (1991) Measuring the existence value of wildlife: What do CVM estimates really show? Land Econ 67:390-400

- Tear TH, Kareiva P, Angermeier PL, Comer P and others (2005) How much is enough? The recurrent problem of setting measurable objectives in conservation. Bioscience 55:835-849

Thorpe A, Failler P, Bavnick JM (2011) Marine protected areas (MPAS) special feature: editorial. Environ Manage 47:519-524

Toonen RJ, Wilhelm TA, Maxwell SM, Wagner D and others (2013) One size does not fit all: the emerging frontier in large-scale marine conservation. Mar Pollut Bull 77:7-10

> Walmsley SF, White AT (2003) Influence of social, management and enforcement factors on the long-term ecological effects of marine sanctuaries. Environ Conserv 30: 388-407

- Warner TE, Pomeroy RS (2012) Creating compliance: a cross-sectional study of the factors associated with marine protected area outcomes. Mar Policy 36:922-932

> White C, Halpern BS, Kappel CV (2012) Ecosystem service tradeoff analysis reveals the value of marine spatial planning for multiple ocean uses. Proc Natl Acad Sci USA 109:4696-4701

White JW, Scholz AJ, Rassweiler A, Steinback C and others (2013) A comparison of approaches used for economic analysis in marine protected area network planning in California. Ocean Coast Manage 74:77-89

Witt MJ, Godley BJ (2007) A step towards seascape scale conservation: using vessel monitoring systems (VMS) to map fishing activity. PLoS ONE 2:e1111

Zacharias MA, Roff JC (2001) Use of focal species in marine conservation and management: a review and critique. Aquat Conserv 11:59-76

Submitted: June 5, 2013; Accepted: May 22, 2014

Proofs received from author(s): October 8, 2014 